\title{
The study on the heat recovery from air compressors
}

\author{
Mariusz Broniszewski ${ }^{1}$, and Sebastian Werle $^{2, *}$ \\ ${ }^{1}$ Bulten Polska S.A., Bukietowa Street 60, 43-300 Bielsko-Biała, Poland \\ ${ }^{2}$ Silesian University of Technology, Institute of Thermal Technology, Konarskiego Street 22, 44-100 Gliwice, Poland
}

\begin{abstract}
Effective use of utilities in production plants is an issue that is becoming increasingly significant in energy policy of Europe. Production of compressed air consumes 3\% of the total electricity consumption in Europe. In order to produce compressed air, approximately $10-20 \%$ of electricity transferred to compressor is used, the rest is lost due to lack of tightness and heat losses. The aim of this work is to evaluate the possibility to install recovery systems on air compressors to recover the lost waste heat and its management for the needs of heating office buildings/production halls and analysis of investment profitability. The investment will be supported by co-financing in the form of energy efficiency certificates (so-called white certificates), which the production plant will be able to sell after receiving them from Polish Energy Regulatory Office in return for completing an investment that consists recovering waste heat from air compressors.
\end{abstract}

\section{Introduction}

In the present world, increasing importance is attached to conducting activity in harmony with sustainable development of a company. It means that while planning company's operations, all aspects that may have an influence on the surrounded environment have to be taken into consideration. One of the aspects that have the biggest impact on the environment, which commonly occurs, is the utilities consumption, including the electricity consumption. Figure 1 shows the amount of the electricity is consumed in the world within different types of sectors. The CAS (compressed air systems) according to Diego Vittorini and Roberto Cipollone [1] is responsible for up to $20 \%$ industry electricity consumption. As we can see, there is a great potential of energy we can save/recover from compressed air systems. The CAS, which is energy demand subprocess for many companies, has also a great potential for improvements under both the energy and $\mathrm{CO}_{2}$ emissions point of view.

The structure of electricity generation sources in Poland is based on coal. The electricity generation using this fuel is characterized by a high index of emission. Due to this fact, the effectiveness of the energy use by the enterprises have to increase. The standard emission index of the electricity generated in Poland equals to $1.191 \mathrm{t} \mathrm{CO}_{2} / \mathrm{MWh}$, whereas the European average equals to $0.460 \mathrm{t} \mathrm{CO}_{2} / \mathrm{MWh}$ [2]. European standard emission indexes for particular countries are presented in Figure 2.

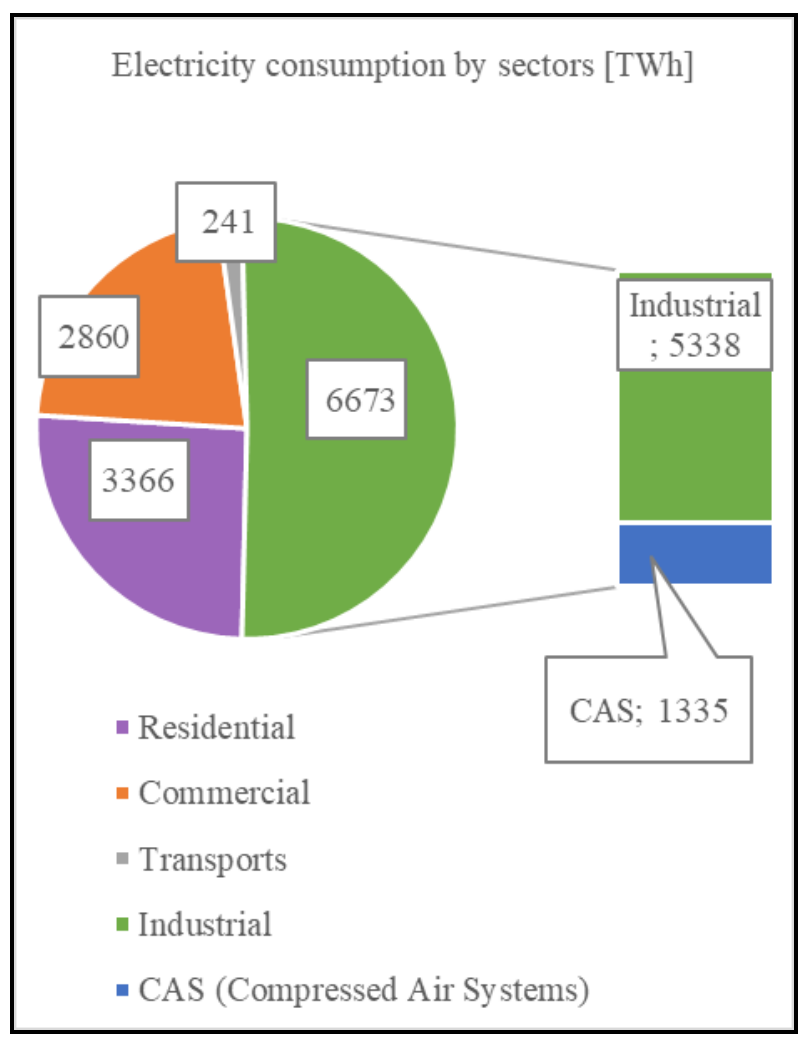

Fig. 1. Electricity consumption by sectors [1].

\footnotetext{
Corresponding author: sebastian.werle@polsl.pl
} 


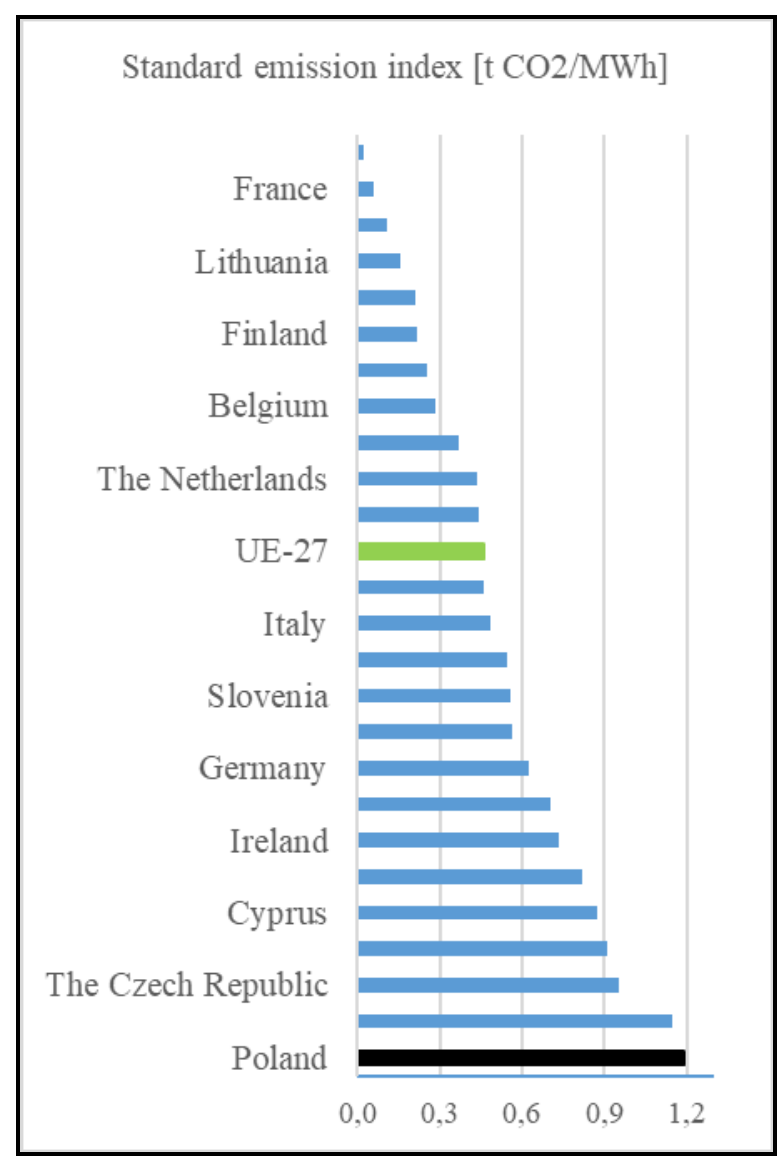

Fig. 2. National and European emission indexes related to electricity consumption [2].

As was mentioned above, the electricity in Poland is mostly produced from coal. In 2009-2012, more than 93\% of total electricity produced in Poland was based on the coal combustion. Due to increasingly strict European Union Directives, Poland had to start to limit the use of this raw material, at the same time increase production of energy from renewable energy sources (RES). Not only European guidelines cause that Polish coal has to be replaced. Another reason is the fact, that nowadays coal production from the coal mine is becoming more difficult. Coal must be mined from deeper layers, so the mines are becoming unprofitable. Moreover, deposits of coal are slowly running out. For example, PGE Group (Polish Energy Group) [2] which manages the power plant in Bełchatów, estimates that deposits in the nearby mine will run out within next three years. Consequently, Poland is facing the challenge. The alternative fuels have to be found and energy production from RES have to be increased [3]. Additionally, the new solutions aiming at maximizing effectiveness of electricity use have to be proposed.

The aim of the work is to analyse profitability of installing recovering heat systems on compressors in Bulten Poland S.A. and estimate simple payback time (SPBT). This will help in order to being independent from heat supplier and will lead to reuse waste heat for their purposes, reducing simultaneously $\mathrm{CO}_{2}$ emission and increasing energy efficiency in the company. Compressed air is significant utility for many of industrial companies, and because of that fact, there are variety possibilities of implementing this solution into industry.

Additional benefit that can be achieved from investments within improving energy efficiency in company can be possibility for obtaining energy efficiency certificates (so-called white certificates) which can be sold on the market bringing the company money and shortening simple payback time of the investment. This study will analyse simple payback time of proposed solution with and without taking into account energy efficiency certificates to show the big value of the motivation in the form of white certificates.

\section{Present energy efficiency issues}

Observing changes in energy consumption in the EU in the years 1990-2012, we can notice opposing tendencies in various sectors. While in agriculture and forestry, or in industry, there was a decrease in energy consumption respectively by $24.6 \%$ and $23.1 \%$, the increase was noticed in the services sector by $36.6 \%$ and in transportation by $23.8 \%$. These changes are partly the result of actions taken to increase energy efficiency [4]. The greenhouse gas emissions from the industrial sector have also changed [5]:

- for industrial processes: 462 million tonnes $\mathrm{CO}_{2}$ in 1990, 394 million tonnes in 2000, 403 million tonnes for 2005, 321 million tonnes in 2012,

- for manufacturing and construction industries: 861 million tonnes in 1990, 707 million tonnes in 2000, 663 million tonnes in 2005, 533 million tonnes in 2012 .

In 2008-2012, retail electricity prices for industry increased in the EU by an average of $3.5 \%$ per year and gas prices by $1 \%$. It is estimated that electricity prices for industry in the EU are twice as high as in the US and Russia and 20\% higher than in China [4].

Measures aiming at increasing energy efficiency may be somehow independent, may also be linked to environmental audits, and in larger enterprises may be a valuable, mandatory element of the management. The initial step to assess the potential benefits of using measures to improve energy efficiency in the company is energy audit. According to Directive 2012/27 / EU [6], an energy audit means a systematic procedure aimed at gaining adequate knowledge about the profile of existing energy consumption of a given activity or industrial plant, determining how and in what quantity it is possible to obtain cost-effective energy savings and to inform about the results of its.Proposed solution in the study was preceded by the proper energy audit which consisted analysis of potential energy savings investments in the company. From several proposals one was chosen as the most efficient and economically reasonable- recovering heat form compressors.

\section{Compressed air in industry}

The aspect of compressed air that is very often ignored in production plants, is the cost of its generation (electricity consumption) which in the significant manner may unnecessarily overstate production costs 
(pressure losses at pipelines, leakages). One of methods for rational use of electricity transferred to an air compressor is heat collection, which is produced as a byproduct at compressed air production. Thus, electricity is directly transformed into compressor operation and indirectly into heat, which can be introduce to the central heating system and, as a result, provide appropriate temperature in offices and production halls. Then the heat consumption from grid, which in Poland is also mostly produced from coal, is limited. Additionally, the carbon footprint of an enterprise (carbon dioxide emission index, that is the amount of emitted $\mathrm{CO}_{2}$ and other substances, calculated for $\mathrm{CO}_{2}$ equivalent that an enterprise emits to the atmosphere as a result of its activity) is limited [6].

Compressed air is considered to be cheap, or even free source of energy. However, this is a wrong approach. Production of compressed air consumes 3\% of the total electricity consumption in Europe. About 10$20 \%$ of electricity transferred to the compressor is used for production of compressed air, the rest is lost due to lack of tightness and heat losses [7,8].

For the needs of European Union countries, proposals of savings in compressed air systems were developed, with determination of savings potential according to index of possibility to apply, given as percentage values. The following operations were highlighted:

- Reduction of air leaks,

- Reduction of pressure losses that result from friction,

- Appropriate designing of new compressed air systems,

- More frequent changes of filters,

- Compressors upgrading,

- Variable rotary drives,

- High performance electric motors,

- Application of advanced Control systems,

- Waste heat recovery,

- Improvement of cooling, drying and filtration systems,

- Adjusting appropriate final devices (receiving) [8,9]

Energy costs during the utilization time of a compressor may reach more than $75 \%$ of the total cost during life cycle (as shown in Figure 3). It has been claimed that improvements within energy efficiency of compressors can bring energy savings in amount of 20$50 \%$ energy used for their running $[10,11]$.

The cost of compressed air, depending on electricity price and devices efficiency in Bulten Poland SA is estimated for approximately $0.04 \mathrm{PLN} / \mathrm{m}^{3}$. In one of the industrial plants that produces connecting materials for automotive industry, calculations were made at the price of $0.04 \mathrm{PLN} / \mathrm{m}^{3}$ and monthly compressed air consumption of $1774632 \mathrm{~m}^{3}$, monthly costs of compressed air production (without taking into consideration exploitation costs) amounted to PLN 70 985.28. During compressed air production, waste heat is generated as by-product, which the company decided to develop. Because of high maintenance costs of producing compressed air in industrial area solutions aimed at reducing costs and increasing energy efficiency are required.
Life cycle costs of compressed air system

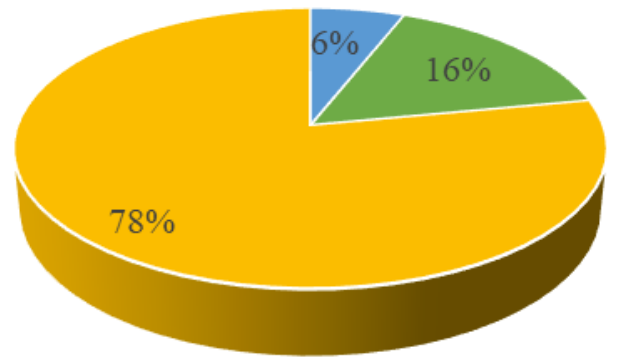

- Maintenance cost - Investment cost

- Energy cost

Fig. 3. Life cycle costs of compressed air system [10].

\section{The possibilities of recovering waste heat from air compressors, the example of Bulten Poland S.A.}

Bulten Poland SA is a factory producing fasteners for the automotive industry, which means that in the production process, the company uses a significant amount of compressed air, e.g. at the stage of pressing and rolling of products. The compressed air is essential utility for such a production, therefore proper compressed air system is very important for maintaining high production standards.

Generation of compressed air is always related to the need of cooling it. Compressed air or a factor mediating in heat exchange (e.g. oil) is cooled by a forced ambient air flow (smaller compressors) or by cooling water (bigger compressors). In both cases, it is possible to restore this heat and use it for useful purposes. Heat restore from positive displacement compressors (e.g. screw), consists of cooling oil (oil as coolant and greasing agent) in a heat exchanger, where on the secondary side heating water flows. Oil circulation is characterized by relatively high temperature (up to $90^{\circ} \mathrm{C}$ ), so factor collecting heat (water) may be heated to usefully high temperatures.

In heating substation rooms, there is an isolated compressor room with screw compressors, oil compressors cooled by air, produced by BOGE Kompressoren Otto Boge $\mathrm{GmbH} \& \mathrm{Co}$. Due to a small distance between heating substation devices from the planned heat recovery systems, there are very favourable conditions for effective connecting both systems and waste heat recovery from compressors.

For the purposes of heat recovery from warm oil that cools compressors, an external heat recovery system "Duotherm" is envisaged, delivered by compressors producer BOGE. The system is based on a plate heat exchanger, to which oil circulation is channelled from the compressor and water circulation from recovery 
installation. The amount of heat collected in the exchanger is regulated by an integrated three-way valve with a thermostatic actuator. Water flow in compressors circulations is forced by operation of variable rotary pumps, controlled by an analogue signal in order to keep constant water temperature, measured behind recovery exchangers. The flow of heated water is directed towards the heat buffer that at the same time serves as a hydraulic clutch. In order to measure the amount of obtained heat, it is planned to install a calorimeter LC1 [12].

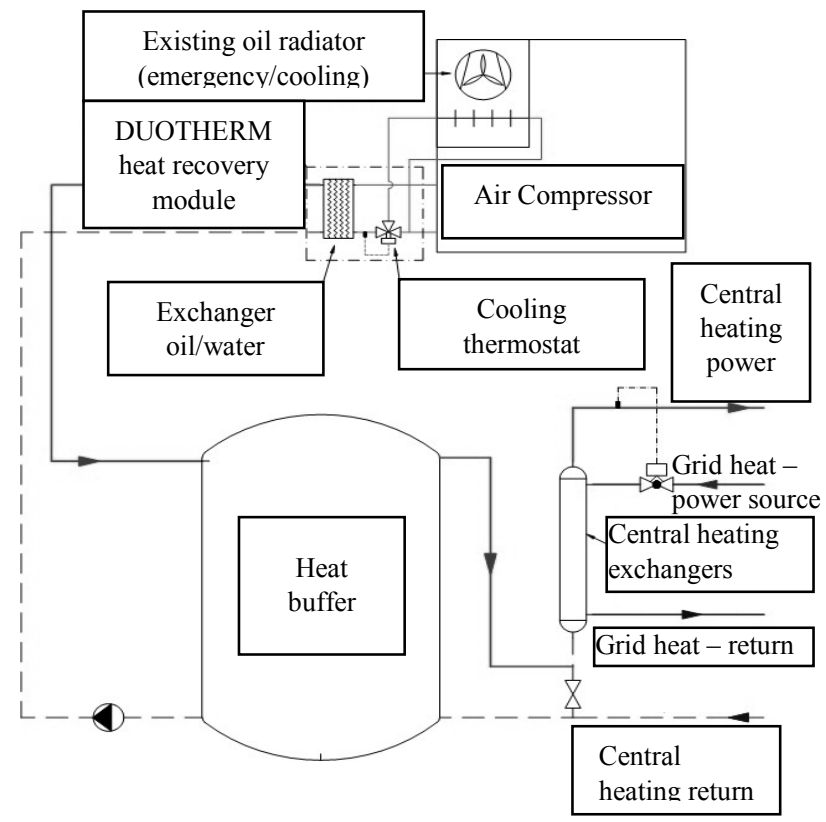

Fig. 4. Heat recovery scheme.

The planned installation of heat recovery from compressors, that is presented as block diagram at Figure 4 will contain such main devices as:

- Heat recovery module "DUOTHERM" for each compressor:

Duotherm 150 for compressor SD-150

2 pcs. Duotherm 100 for compressor SD-100/SD-90

2 pcs. Duotherm 60 for compressors SD-60

- Heat buffer(s) of the total volume of about $10 \mathrm{~m}^{3}$ for balancing variability of heat recovery and heat collection and to hydraulic compression of systems.

- Circulating pumps of the heat recovery system. Depending on the accepted design solution, each module may have its own pump or it is also possible to apply one pump and a direct-run distribution system with automatic shut-off valves.

- Automatics controlling the heat recovery system and contributing to maximization of heat recovery (control cabinets, programmable controller, automation devices).

- Calorimeter for counting the amount of the heat obtained from the compressors.

- Piping and installation fittings necessary for connecting systems and appropriate operation of the installation.

A compressor room, due to its constant operation nature and a relatively regular power, may be a very stable source of waste heat. Compressors operate in a cascade, depending on demand for compressed air. Usually, all compressors are in motion, whereas one of them (mostly SD-150) serves a "driving in" function, i.e. depending on the pressure in the compressed air grid, it operates in load/lighten mode (neutral gear). Some of the Company Departments Plant work 7 days a week (e.g. Department of Heat Treatment), the other - 5-6 days a week. For each compressor, powers of the main drive, the fan and the total nominal power were determined and calculated energy consumption. Additionally, average power input and load index was determined. The data is presented in Table 1.

Table 1. Energy powers and consumption by particular air compressors [12].

\begin{tabular}{|c|c|c|c|c|c|c|c|}
\hline$\dot{0}$ & 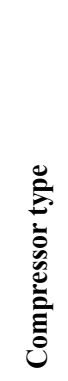 & 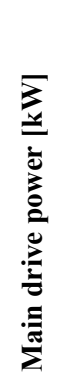 & 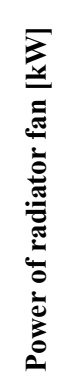 & 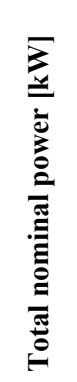 & 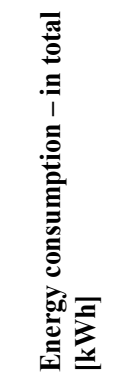 & 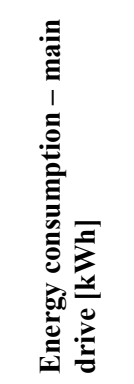 & 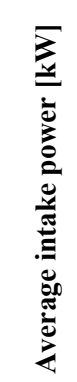 \\
\hline 1. & $\begin{array}{l}\text { SD- } \\
150 \\
\end{array}$ & 110 & 4.0 & 114 & 760510 & 733825 & 100.3 \\
\hline 2. & $\begin{array}{l}\text { SD- } \\
100\end{array}$ & 75 & 2.2 & 77.2 & 582644 & 566040 & 76.8 \\
\hline 3. & $\begin{array}{l}\text { SD- } \\
90^{*}\end{array}$ & 65 & 2.2 & 67.2 & 484163 & 468312 & 63.8 \\
\hline 4. & $\begin{array}{l}\text { SD- } \\
60^{*}\end{array}$ & 45 & 1.5 & 46.5 & 335023 & 324216 & 44.2 \\
\hline 5. & $\begin{array}{l}\text { SD- } \\
60^{*}\end{array}$ & 45 & 1.5 & 46.5 & 335023 & 324216 & 44.2 \\
\hline \multicolumn{2}{|c|}{ In total } & 340 & 11.4 & 351.4 & 2497363 & 2416609 & 329.3 \\
\hline
\end{tabular}

*Metering of energy consumption is only at compressors SD-150 and SD-100. Energy consumption by remaining compressors was estimated on the basis of work time and power of drives.

The possibilities to recover heat from compressors are mostly based on heat collection from warmed-up oil, which circulates in internal compressor circulation as a coolant and a greasing agent. This heat is received by the heat exchanger, where mostly $65 \div 75 \%$ of energy transferred to the compressor drive may be recovered. The compressor value declared by the producer, i.e. $72 \%$ was assumed for calculations.

Monthly demand for heat with waste heat potential possible to recover is presented in Table 2 . The amount of heat obtained from the recovery installation and usefully used for the needs of central heating was estimated.

Demand for heat was determined on the basis of 'degree-days', through which heat consumption was calculated, expressed as the standard season, taking real data from years 2014 and 2015 for calculation; the amounts were compared to average monthly temperatures from the past 10 years. 
In order to calculate profitability of the investment and payback time, one should compare the heating costs incurred before modernization (Figure 5 and Figure 7) and the heating costs after modernization (Figure 6 and Figure 8) and use of waste heat recovered from air compressors for this purpose. Total costs of heat before and after modernization have been shown in Figure 9.

Fixed and variable costs have been calculated with following formulas:

Fixed cost:

$$
K_{f}=12 \cdot \Sigma_{O s} \cdot q_{0}
$$

Variable costs:

$$
K_{V}=Q_{\text {real }} \cdot \Sigma_{O z}
$$

where:

Os - sum of fixed charges for ordered power [PLN / $\mathrm{MW} /$ month]

$\Sigma_{O Z}$ - the sum of variable fees for heat consumption, for distribution services, etc. [PLN / MW]

$q_{0}$ - ordered power [MW]

$Q_{\text {real }}$ - the amount of heat consumption [MW]

Table 2. Monthly demand for heat with the waste heat

\begin{tabular}{|c|c|c|c|c|c|c|c|}
\hline 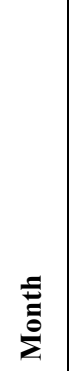 & 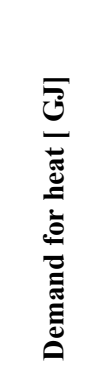 & 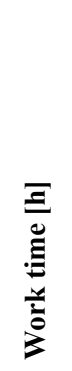 & 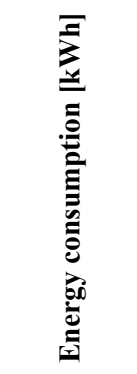 & 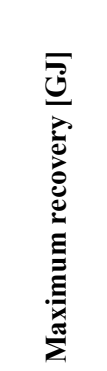 & 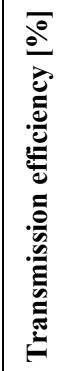 & 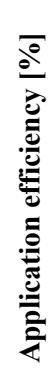 & 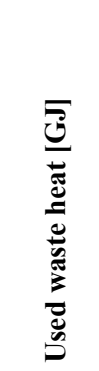 \\
\hline I & 1530.1 & 696 & 229188 & 574.8 & 95 & 98 & 535.2 \\
\hline II & 1428.9 & 624 & 205479 & 515.4 & 95 & 98 & 479.8 \\
\hline III & 959.5 & 696 & 229188 & 574.8 & 95 & 94 & 513.3 \\
\hline IV & 669.3 & 672 & 221285 & 555.0 & 95 & 90 & 474.5 \\
\hline V & 50.2 & 696 & 229188 & 574.8 & 95 & 9 & 50.2 \\
\hline VI & 0.0 & 672 & 221285 & 555.0 & 95 & 0 & 0.0 \\
\hline VII & 0.0 & 696 & 229188 & 574.8 & 95 & 0 & 0.0 \\
\hline VIII & 0.0 & 384 & 126449 & 317.2 & 95 & 0 & 0.0 \\
\hline IX & 12.5 & 696 & 229188 & 574.8 & 95 & 2 & 12.5 \\
\hline $\mathrm{X}$ & 613.8 & 672 & 221285 & 555.0 & 95 & 90 & 474.5 \\
\hline XI & 970.4 & 696 & 229188 & 574.8 & 95 & 94 & 513.3 \\
\hline XII & 1374.5 & 384 & 126449 & 317.2 & 95 & 98 & 295.3 \\
\hline$\sum$ & 7609.1 & 7584 & 2497363 & 6264.0 & - & - & 3348.8 \\
\hline
\end{tabular}
potential possible to recover [12].
Fixed costs before modernization

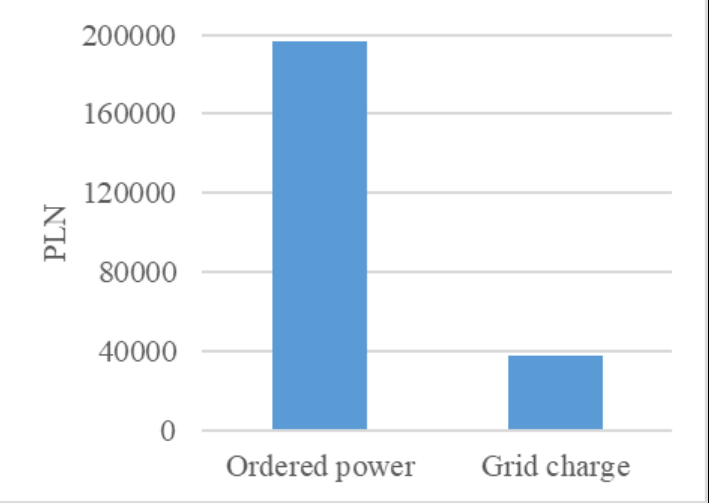

Fig. 5. Fixed costs before modernization [13].

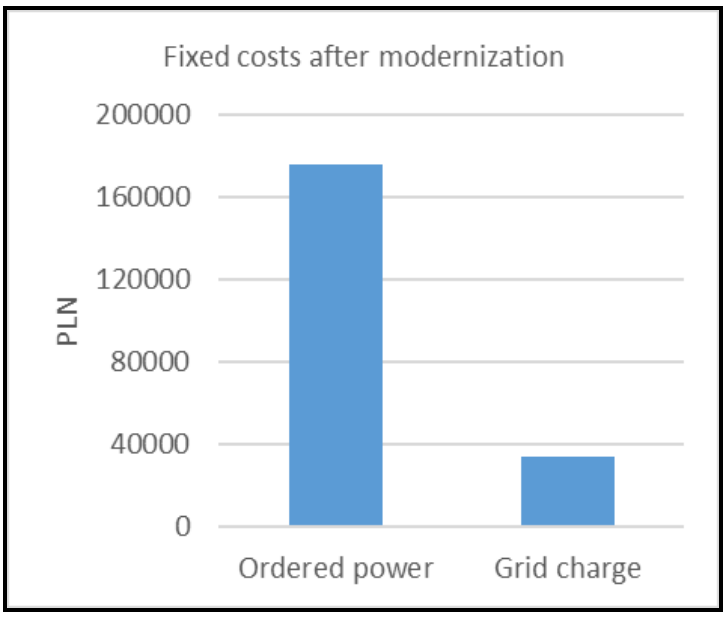

Fig. 6. Fixed costs after modernization [13].

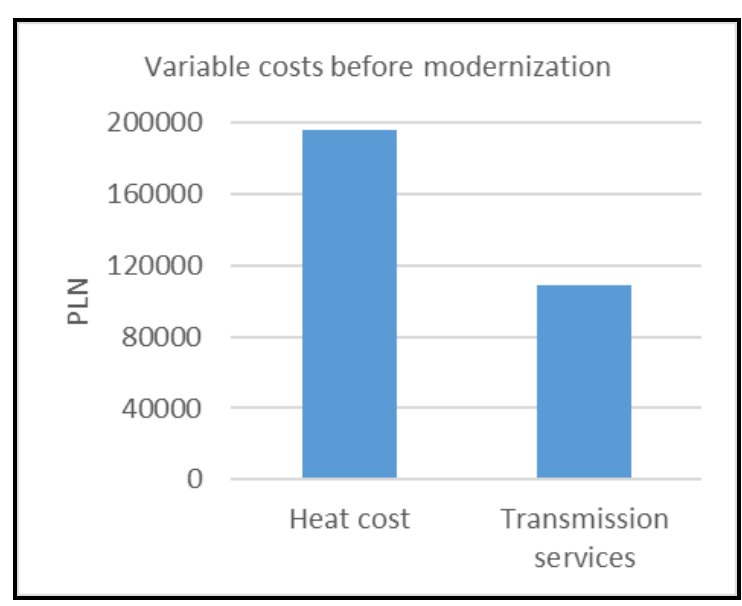

Fig. 7. Variable costs before modernization [13]

Table 3 shows consumption calculation costs of additional electricity devices, estimated modernization costs expenditures and simple investment payback time (SPBT) 


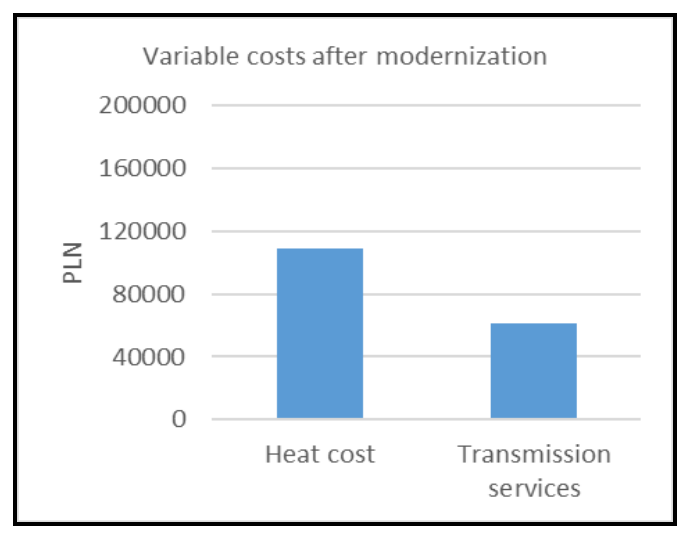

Fig. 8. Variable costs after modernization [13]

Table 3. Costs of additional electricity devices and estimated costs of modernization with SPBT.

\begin{tabular}{|c|c|c|}
\hline \multirow{3}{*}{ 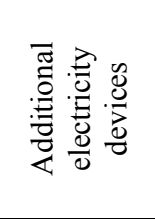 } & $\begin{array}{l}\text { Electricity consumption to drive } \\
\text { additional devices }\end{array}$ & $\begin{array}{l}4,800 \\
\mathrm{kWh}\end{array}$ \\
\hline & $\begin{array}{l}\text { Average unit variable cost of } \\
\text { electricity }\end{array}$ & $\begin{array}{l}65 \mathrm{EUR} \\
\text { /MWh }\end{array}$ \\
\hline & $\begin{array}{l}\text { Cost of consumption of additional } \\
\text { electricity after modernization }\end{array}$ & $\begin{array}{l}315 \text { EUR } \\
\text { /year }\end{array}$ \\
\hline \multirow{3}{*}{ 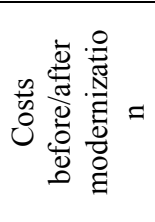 } & $\begin{array}{lll}\begin{array}{l}\text { Exploitation } \\
\text { modernization }\end{array} & \text { cost } & \text { before } \\
\end{array}$ & $\begin{array}{l}125313 \\
\text { EUR /year }\end{array}$ \\
\hline & $\begin{array}{lll}\begin{array}{l}\text { Exploitation } \\
\text { modernization }\end{array} & \text { cost } & \text { after } \\
\end{array}$ & $\begin{array}{l}88741 \\
\text { EUR /year }\end{array}$ \\
\hline & Annual savings for heat recovery & $\begin{array}{l}157255 \\
\text { PLN/year }\end{array}$ \\
\hline \multirow{8}{*}{ 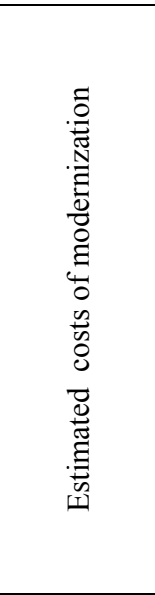 } & $\begin{array}{l}\text { Installation design and trade- } \\
\text { specific agreements }\end{array}$ & $\begin{array}{l}2325 \\
\text { EUR }\end{array}$ \\
\hline & $\begin{array}{l}\text { Installation of } 5 \text { "DUOTHERM" } \\
\text { heat recovery modules }\end{array}$ & $\begin{array}{l}23255 \\
\text { EUR }\end{array}$ \\
\hline & Heat buffers & $\begin{array}{l}3256 \\
\text { EUR }\end{array}$ \\
\hline & $\begin{array}{lll}\begin{array}{l}\text { Automatics driver } \\
\text { (valves and pumps) }\end{array} & \text { elements } \\
\end{array}$ & $\begin{array}{l}5814 \\
\text { EUR }\end{array}$ \\
\hline & $\begin{array}{l}\text { Control automatics (driver, } \\
\text { sensors, cables) }\end{array}$ & $\begin{array}{l}4651 \\
\text { EUR }\end{array}$ \\
\hline & $\begin{array}{l}\text { Fittings, pipelines, refractory } \\
\text { shapes, insulation }\end{array}$ & $\begin{array}{l}3488 \\
\text { EUR }\end{array}$ \\
\hline & Installation works and start-up & $\begin{array}{l}8372 \\
\text { EUR }\end{array}$ \\
\hline & $\begin{array}{l}\text { IN TOTAL (investment costs } \\
\text { related to concept) }\end{array}$ & $\begin{array}{l}51161 \\
\text { EUR }\end{array}$ \\
\hline SPBT & Simple investment payback time & 1.4 (years) \\
\hline
\end{tabular}

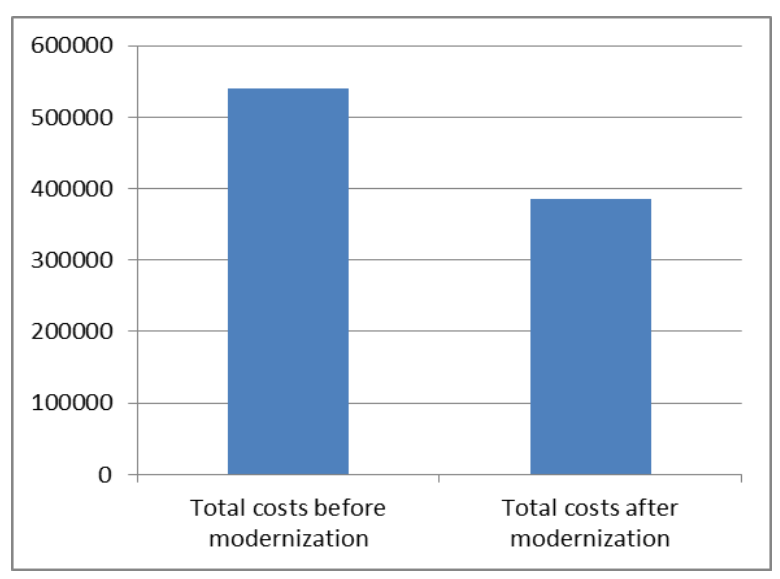

Fig. 9. Total costs of heat before and after modernization [13].

\section{White certificates}

The system of energy efficiency certificates, so-called "white certificates", uses market mechanisms to support increasing energy efficiency. For entrepreneurs, this is an opportunity to receive additional cash for modernization that resulting in energy savings in the enterprise. However, it should be remembered that the system can only be used for new investments. The exception is the transitional period, valid until 30 September 2017, when latecomers can still apply to the President of URE (Energy Regulatory Authority) for white certificates for projects that were completed in the period from January 1, 2014 to September 30, 2016. Each entrepreneur can benefit from the white certificates system if meets the conditions imposed by the Energy Efficiency Act, conducts an energy efficiency audit, and the application submitted will be considered positively by the President of the Energy Regulatory Authority.

When talking about the tender, one need to be aware that formally we dealt with tender procedures for projects of three categories:

- Increasing electricity saving by end-users,

- Increasing electricity saving by devices for own needs,

- Lowering electricity, heat or natural gas losses in transmission or distribution [14].

Bulten Polska S.A. took part in the tender procedure for white certificates no. 1/2015, announced on 29 December 2015. The proposed solution name was: Waste heat recovery from the compressors for the needs of plant heating. The concept involved increasing electricity saving at end-user by useful application of waste heat from cooling the compressors. Submitting documents for the tender procedure was preceded by a profound analysis of profitability and calculation of the size of electricity saving resulting from implementation of the abovementioned solution. This value is expressed as toe (equivalent amount of one ton of mineral oil of net calorific value equal to $41.868 \mathrm{GJ}$ or $11.63 \mathrm{MWh}$ ) [15]. URE (Energy Regulatory Authority) granted to Bulten Polska S.A. white certificates of the value equal to 53.00 toe for implementation of proposed solution that comprises installation of recovery systems of waste heat from air compressors, which after sale generated profit of 11660 EUR (average price for 1 toe was 220 EUR). The profit from sale of white certificates significantly lowered anyways profitable payback time.

Tab. 5 shows how much decrease the payback time taking into account benefits from white certificates.

Table 4. Simple investment payback time after deduction benefit from white certificates.

\begin{tabular}{|l|l|}
\hline $\begin{array}{l}\text { IN TOTAL (investment costs related to } \\
\text { concept) }\end{array}$ & 51161 EUR \\
\hline Profit from white certificates & 11660 EUR \\
\hline $\begin{array}{l}\text { IN TOTAL (after deduction benefit from } \\
\text { white certificates) }\end{array}$ & 39501 EUR \\
\hline Simple investment payback time & 1.1 (years) \\
\hline
\end{tabular}




\section{Conclusions}

Modern European politics strongly emphasises promoting sustainable development in enterprises. That is why, we mostly need to aim at increasing entrepreneurs' awareness in rational use of utilities, such as electric current or heating. The result of increasing awareness should be planning activities that would aim at increasing energy efficiency in production plants (and not only) by analyses (starting from even the simplest) of profitability of investment in recovery systems of waste heat from technological processes of production plants and secondary processes (e.g. such as production of compressed air). The companies that have to produce compressed air in their activity, should cautiously look at the entire compressed air system, it turns out that this utility, even though often ignored, proves great potential for application in heat recovery systems and of using it for own needs.

Above presented results show, that recovering heat form air compressors are profitable and can be successfully implemented in industrial area, in companies that use compressed air in their production processes. Additional advantage of implementing this kind of solution for improving energy efficiency is possibility for gaining white certificates, which can significantly shorten payback time of the investment.

\section{References}

1. D. Vittorini, R. Cipollone. Energy 102, p. 502-515 (2016). Energy savings potencial in existing industrial compressors.

2. Technical enclosure to instruction for filling SEAP template: Emission index, http://www.soglasheniemerov.eu/IMG/pdf/technica 1_annex_pl.pdf, (on-line 08.11.2017).

3. Electricity production in Poland, https://energiadirect.pl/poradniki/produkcjaenergii-elektrycznej-w-polsce, (on-line 08.11.2017).

4. T. Skoczkowski, S. Bielecki, Energetyka 1, p. 9-14 (2016). Measures to improve Energy efficiency in industry and their evaluation.

5. Smarter, greener, more inclusive? Indicators to support the EU. Europe 2020 strategy. Eurostat Statistical Books, (2015).
6. Directive 2012/27/EU of the european parliament and of the council of 25 october 2012 on energy efficiency

7. Conscious choices of consumers - product's carbon footprint,

http://www.akademiaodpadowa.pl/445,a,12swiadome-wybory-konsumenckie-slad-weglowyproduktu.htm, (on-line 08.11.2017).

8. Compressed air as form of energy, http://www.silvent.com/pl/w-czym-mozemypomoc/optymalizacja-energii/sprezone-powietrzejako-forma-energii/, (on-line 08.11.2017).

9. Energy efficiency of compressed air systems, http://enspol.eu/sites/default/files/Efektywno $\%$ C5\% 9B $\% \mathrm{C} 4 \% 87 \% 20$ Energetyczna $\% 20$ System $\% \mathrm{C3} \% \mathrm{~B}$ 3w\%20Spr\%C4\%99\%C5\%BConego\%20Powietrza .pdf, (on-line 08.11.2017).

10. S. Mousavi, S. Kara, B. Kornfeld, Procedia CIPR 15, p. 313-318 (2014). Energy Efficiency of Compressed Air Systems.

11. How to save energy in compressed air systems, http://docplayer.pl/3287990-Jak-oszczedzacenergie-w-systemach-sprezonego-powietrza.html, (on-line 06.11.2017).

12. Assessment of possibilities for reusing waste heat to cover needs for heating in Bulten Poland S.A., https://www.researchgate.net/publication/32058512 7 ASSESSMENT_OF_POSSIBILITIES_FOR_RE USING_WASTE_HEATT_TO_COVER_NEEDS_F OR_HEATING_IN_BULTEN_POLAND_SA_OC ENA_MOZLIWOSCI_WYKORZYSTANIA_CIE PLA_ODPADOWEGO_W_CELU_ZASPOKOJE NIA_ZAPOTRZEBOWĀNIA_NA_MOC_GRZE WCZ̄A_W, (13.11.2017).

13. Report from audit of energy efficiency of a project: Waste heat recovery from compressors for the needs of heating plant in Bulten Polska S.A.

14. Experiences from the first tender for white certificates,

http://www.bialecertyfikaty.com.pl/artykuly/doswia dczenia-z-pierwszego-przetargu-na-bialecertyfikaty, (on-line 15.11.2017).

15. M. Robakiewicz. Rynek Instalacyjny 1-2, p. 69-72 (2017). System of White Certificates after the amendment to the Act. 